\title{
Chemical Materials Mastery of High School Students in East Java
}

\author{
Bertha Yonata \\ Chemistry Department \\ Universitas Negeri Surabaya \\ Surabaya, Indonesia \\ berthayonata@unesa.ac.id
}

\begin{abstract}
This article reveals student achievement in the Indonesia National Examination on Chemistry Material at the high school level in the East Java Province from 2015-2016, 20162017, and 2017-2018. The chemistry exam consists of Basic Chemistry, Analytical Chemistry, Inorganic Chemistry, Organic Chemistry, and Physical Chemistry. In the 2015/2016 school year, chemistry exam was compulsory for students who program science while starting the 2016/2017 academic year until 2017/2018 chemistry examination as a test for students who choose chemistry specialization. This test has an impact on the number of students taking chemistry test subjects, the number of students taking the National Examination in the Chemistry test in the 2015/2016, 2016/2017, and 2017/2018 academic years respectively, at 107345 , 15600 and 22367 students. From the national Examination results data reported by Puspendik for East Java Province, an average score of National Examination scores of five chemistry test subjects with an up and downtrend in the range of 48.90 to 64.71 was obtained. If compared, the average National Examination score for each chemical material in the East Java province is higher than the national average
\end{abstract}

Keywords - National Examination chemistry material; high school; average National Examination chemistry score; East Java

\section{INTRODUCTION}

The core competencies that must be obtained and possessed by senior high school students are the core competencies for spiritual attitudes, social attitudes, knowledge, and skills. Attachment to the Minister of Education and Culture Regulation No. 21 of 2016 concerning Basic and Secondary Education Content Standards) [1], [2]. In chemistry subjects at the high school level, five materials are tested on the National Examination. These materials include Basic Chemistry, Analytical Chemistry, Inorganic Chemistry, Organic Chemistry, and Physical Chemistry. In Mathematics and Natural Sciences, Chemistry is one of the productivity subjects which in learning processes students do not only need to understand the concepts, principles, laws, and theories but also its relevance and application to solve problems in daily life [3].

The implementation of the 2013 curriculum also influenced the number of students who chose chemistry (see Figure 1). Based on the data in Figure 1, it can be seen that the number of students taking the chemistry National Examination in 2017 has decreased from 2016 and tends to rise, although not significantly in 2018. The highest number of students each year is senior high school students in the city of Surabaya. The data in Figure 1 are from Balitbang [4], [5], [6].

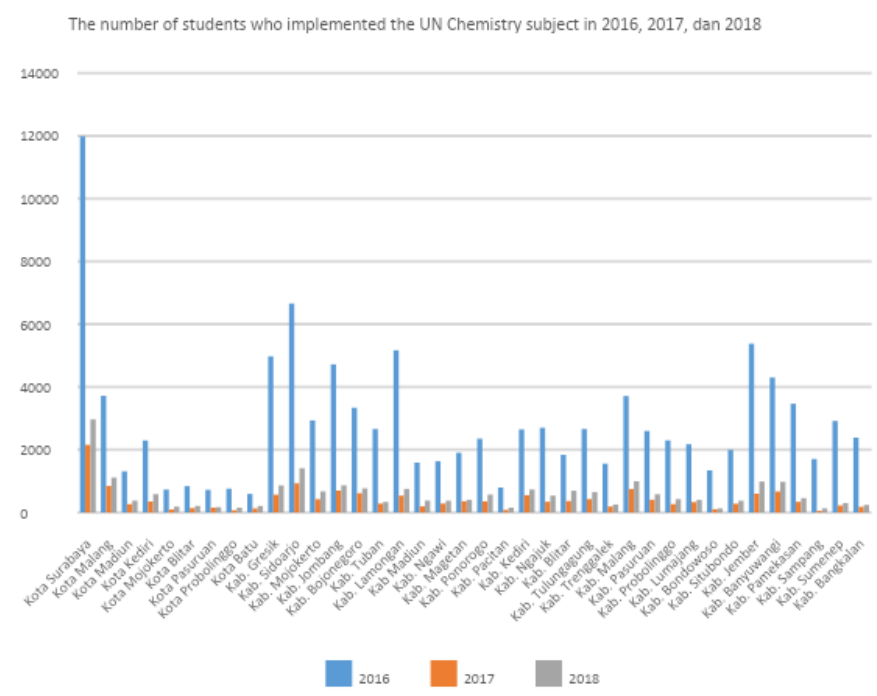

Fig. 1. Comparison of The Number of Students Who Take The Chemistry Exam National Examination in 2016, 2017, and 2018

Chemistry exams in 2016 to 2018 consist of Basic Chemistry, Analytical Chemistry, Inorganic Chemistry, Organic Chemistry, and Physical Chemistry. The exams were started in the 2016/2017 academic year to $2017 / 2018$ chemistry exams as a test for students who choose a specialization in chemistry. This article will present and discuss the data of National Examination Chemistry in senior high school in East Java. The data used are from the Republic of Indonesia Ministry of Education and Culture Republic of Indonesia in 2016, 2017, and 2018 [4]-[6].

\section{METHOD}

Descriptive analysis of National Examination data obtained from Puspendik in 2016, 2017, and 2018. Every year high school students work on national examination questions. There are 40 items for chemistry with analytical chemistry, inorganic chemistry, organic chemistry, physical chemistry, and basic 
chemistry. There are five answer choices available for each question. The time allocation for working on the questions is 120 minutes. The data source came from all high school students throughout East Java who programmed chemistry exams

\section{RESULTS AND DISCUSSION}

\section{A. Comparison of Chemistry National Examination} Achievements in Senior High School in East Java and National Provinces

Figure 2 presents the average comparison of senior high school Chemistry National Examination scores in East Java and National for five exam material in Chemistry subjects from 2016 to 2018 . From the data presented in Figure 2 shows the tendency for National Examination scores of all Chemistry materials for East Java Province to be higher than the national average, except in 2016 for inorganic chemicals. The range of the difference in National Examination material scores in chemistry subjects ranges from 0.44 to 5.96 for all material in chemistry subjects.

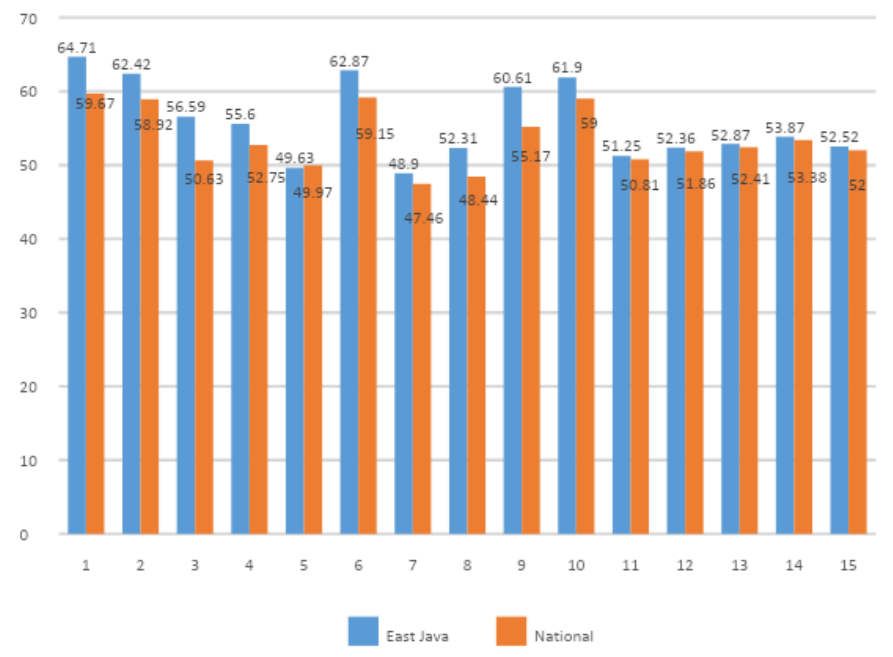

Fig. 2. Comparison of Senior High School National Chemistry National Examination Grade in East Java and National Average

Based on the data in Figure 2, we get the fact that the lowest and highest average values for each year are different. However, the tendency of the lowest and highest values applies equally to the provinces of East Java and nationally. In 2016 the lowest average National Examination score was inorganic chemistry material, 2017 analytical chemistry, and 2018 was basic chemistry while the highest value is basic chemistry material in 2016 and 2017, while in 2018 is organic chemistry material.

If the lowest value of material completeness is 55, then in 2016 for East Java, only inorganic chemistry material has a low achievement, whereas nationally, the physical chemistry, organic chemistry, and inorganic chemistry material get a low achievement. In 2017 there were changes, including analytical chemistry and physical chemistry, which received a low achievement for East Java and national provinces. In 2018 all materials were in a low achieving condition both in East Java and national provinces.

\section{B. Achievements in Chemistry National Examination Senior} High School Students in Districts / Cities in East Java

The following will discuss the senior high school chemical National Examination scores in all districts/cities throughout East Java.

\section{Basic Chemistry}

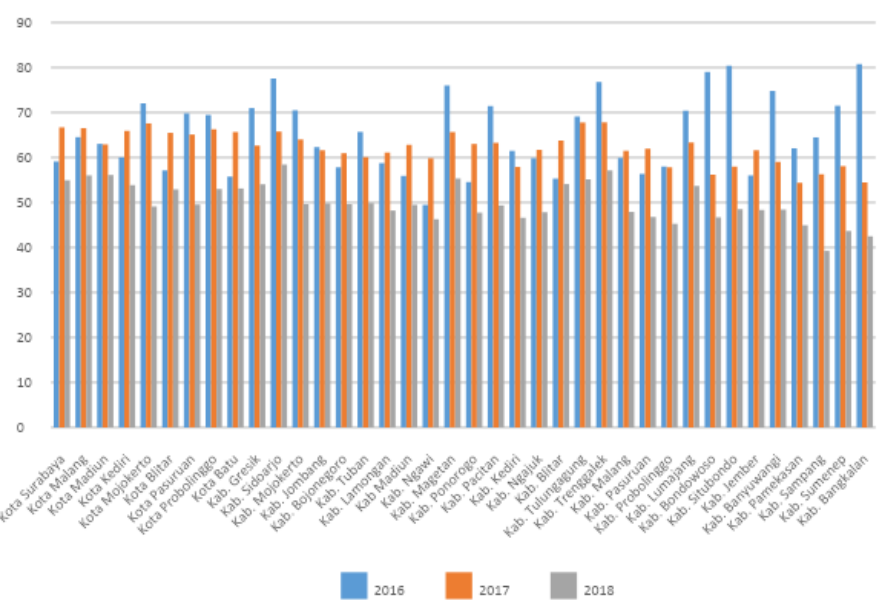

Fig. 3. Average Comparison of Senior High School National Examination Chemistry Values in East Java Year in Basic Chemistry Material

From Figure 3, it can be seen that the value of primary chemistry material experiences different achievements in each city and district in East Java. In 2016 the highest achievement of Basic Chemistry material was obtained by Bangkalan District, which was 80.76; in 2017, Trenggalek District achieved an average value of 67.8 , and in 2018 the highest value was 58.44 achieved by Sidoarjo District. However, in general, the highest value of Basic Chemistry has decreased from year to year.

Analytical Chemistr

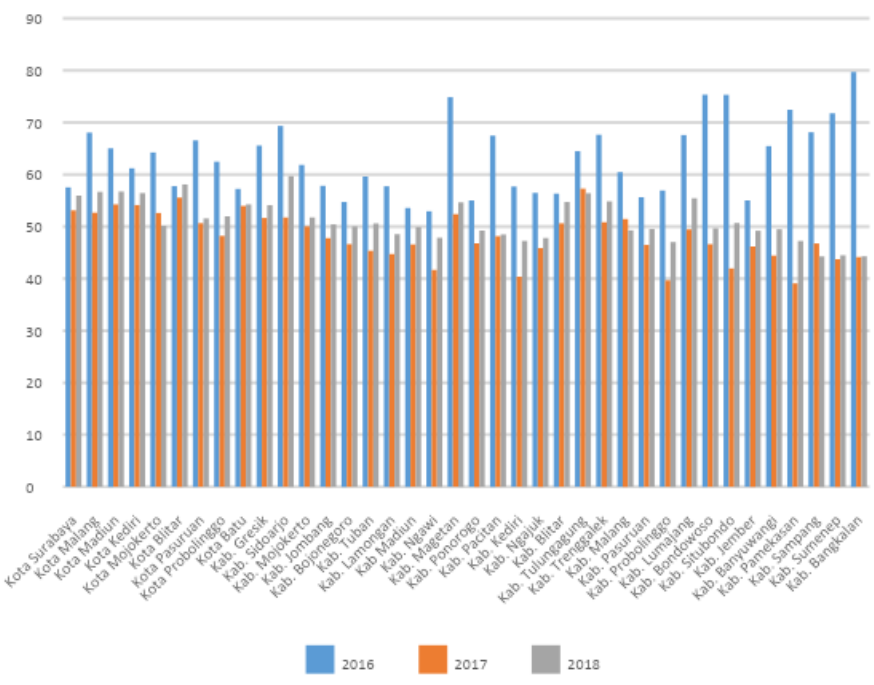

Fig. 4. Average Comparison of Senior High School National Examination Chemistry Values in East Java Year in Analytical Chemistry Material 
The material tested on basic chemistry is stoichiometry, concentration, mole, and limiting reactants. This material is one of the data that students must understand before learning other concepts such as acid-base $\mathrm{pH}$. The findings of the study it was observed that senior secondary students do possess misconceptions in stoichiometry and the mole [7].

Based on the data in Figure 4, it can be seen that the value of analytical chemistry material is different in each city and district in East Java. In 2016 the highest achievement in Basic Chemistry material was obtained in the Bangkalan District, which was 79.68; in 2017, Tulungagung District achieved an average value of 57.29, and in 2018 the highest value was 59.72 achieved by Sidoarjo District. The highest value of Analytical Chemistry has fluctuated from year to year. In 2016, 2017, and 2018 the examination in analytical chemistry asking about titration, hydrolysis of salt, and buffer. The students have to understand the using of $\mathrm{Kb}$ and $\mathrm{Ka}$ to determine the value of $\mathrm{pH}$.

When viewed from the low achievement in analytical chemistry shows that the level of understanding of students in analytical chemistry materials is still low. Several factors cause the low value of students in analytical chemistry, especially acid-base. The first factor is the students' low understanding of metals, periodic tables, ionization energy, atomic size, electronegativity, solubility, and inter-intramolecular forces [8]. The low understanding or the occurrence of misconceptions in students related to the overstuffed nature of introductory chemistry itself, the emphasis during instruction on solving numerical problems, and the dominant role played by the textbook [9].

\section{Physical Chemistry}

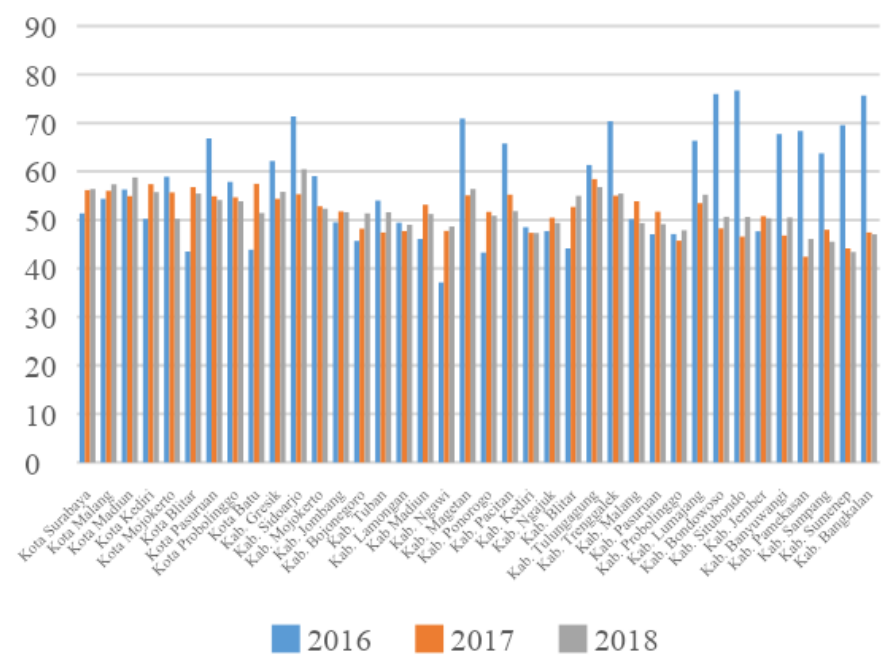

Fig. 5. Average Comparison of Senior High School National Examination Chemistry Values in East Java Year in Physical Chemistry Material

Figure 5 shows fluctuations in the average value of Physical chemistry material in each city and district in East Java. Situbondo District achieved the highest value for Physical Chemistry material, which was 76.7 in 2016. In 2017, Tulungagung District achieved the highest value for Physical chemistry material with a value of 58.44, and in 2018 Sidoarjo
District achieved the highest average value with a value of 60.47. From 2016 to 2018 , the achievement of the highest value has decreased and increased.

The material tested in physical chemistry is thermodynamics, reaction rates, chemical equilibrium, and electrolysis. Misconception can be a factor that causes low national student examination results in physical chemistry. For chemistry equilibrium, some misconceptions regarding chemical equilibrium might be the result of instruction that emphasis correct concepts without highlighting common conceptual errors [10]. Chemistry teachers should be aware of students' prior knowledge and misconceptions by examining why misconceptions occur and use leaming activities to eliminate misconceptions [10].

The study of Ballen shows that the difficulties in chemistry equilibrium showed that the mathematical operationalization of chemical concepts tended to be an additional factor that caused problems during the learning process [11]

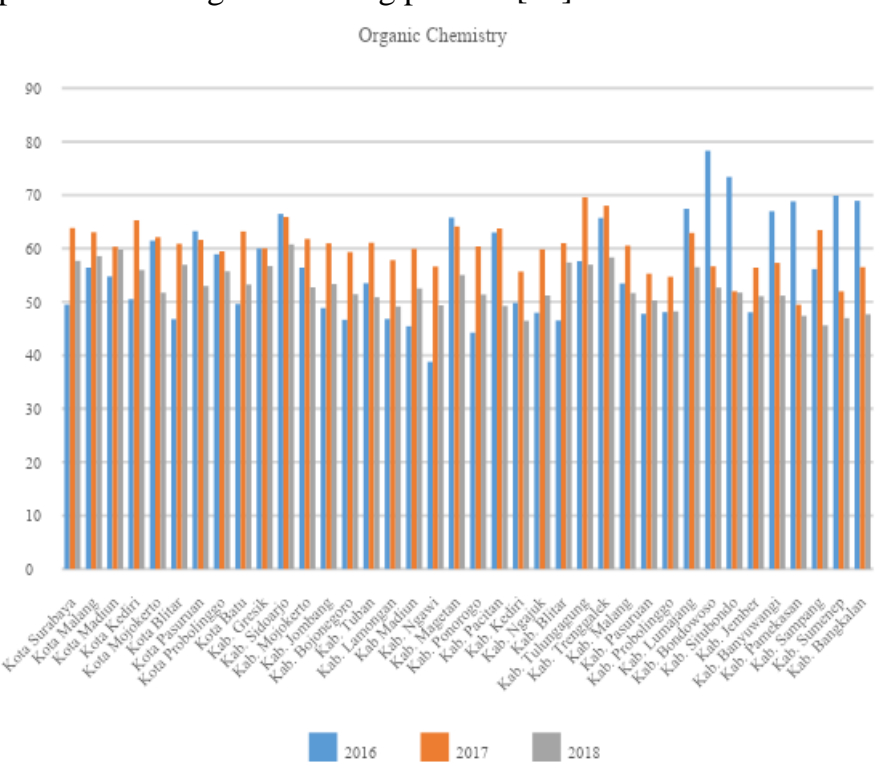

Fig. 6. Average Comparison of Senior High School National Examination Chemistry Values in East Java Year in Organic Chemistry Material

From the data presented in Figure 6 shows the fluctuations in the average value of Organic chemistry material in each city and district in East Java from 2016 to 2018. Bondowoso District achieved the highest value for Physical Chemistry material, which was 78.32 in 2016. In 2017, the Tulungagung District achieved the highest value for organic chemistry material with a value of 69.59. In 2018 Sidoarjo District reached the highest average value with a value of 60.76 . From 2016 to 2018, in general, the achievement of the highest value has decreased.

The low national examination results are usually in the matter of organic matters and reactions. This fact is also corroborated by Omwirhiren's research, which states that student misconceptions occur in the material Substitution and addition reactions of hydrocarbons and apply the IUPAC rules to name compounds appropriately among others [12]. 
Misconceptions experienced by students can cause a low understanding of advanced organic chemistry materials [12].

In Figure 7, it can be observed that the average value in each city and district in East Java fluctuated from 2016 to 2018. Bondowoso Regency achieved the highest value for inorganic Chemistry material, which was 69.79 in 2016. In 2017, Kota Batu received the highest ranking achievement of the average value of inorganic chemistry material that is equal to 69.38 . Sidoarjo Regency achieved the highest average value with a value of 60.96 in 2018. In general, the achievement of the highest value for inorganic chemistry material decreased in the range of 2016 to 2018 .

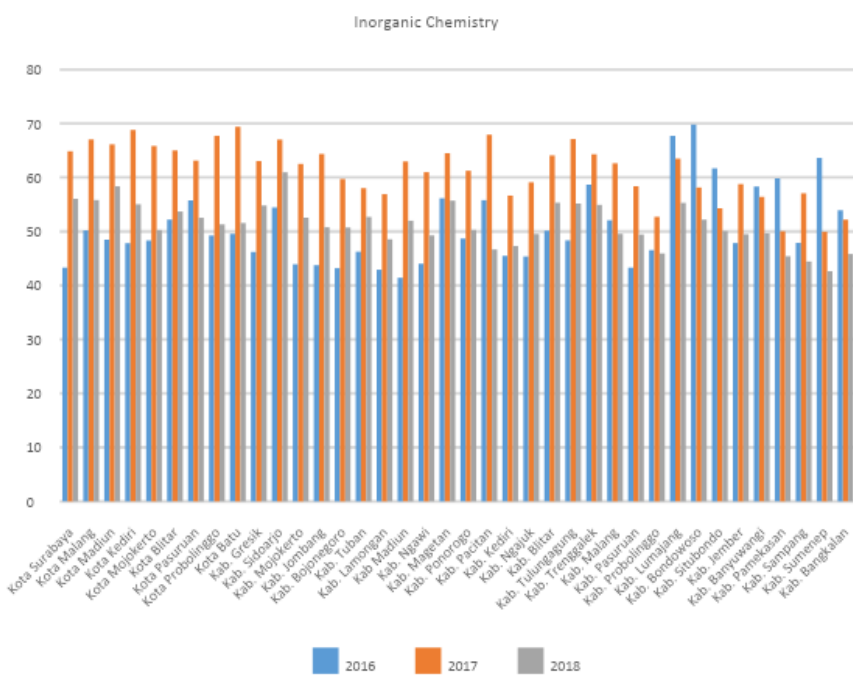

Fig. 7. Average Comparison of Senior High School National Examination Chemistry Values in East Java Year in Inorganic Chemistry Material

The low scores obtained by students in this inorganic material can be overcome, one of them, by way of teachers should try to expose the learners to profitable learning experiences, which are deliberately planned into the lesson to enable learners, acquire individual contact with the concepts being taught [13].

From the analysis of the achievement value of basic chemistry, analytical chemistry, physical chemistry, organic chemistry, and inorganic chemistry material, it shows that the mastery of the material is more in schools from the regency in East Java than from the city area. The city of Surabaya as the most significant contributor to the number of students does not have the highest achievement in all chemical materials and three years (2016-2018). To improve students' understanding of the subject matter in chemistry, the teacher or lecturer must understand the model and technique to make the students easy to understand the topic discussed [14].

\section{CONCLUSION}

Comparative analysis of the value of the National Examination material in chemistry subjects from 2016 to 2018 on average from the province of East Java and nationally shows the tendency of the average value of East Java Province to be higher than the national average. Whereas based on a comparative analysis of UN grades for each chemistry material for senior high school students in Sidoarjo Regency, Trenggalek Regency, Tulungagungm Regency, Bondowoso Regency, Situbondo Regency, and Batu City, and Bangkalan District contributed the highest average value in chemical materials in 2016 to 2016. 2018. In general, the average value of each material has decreased over the past three years.

\section{REFERENCES}

[1] Kemendikbud, Permendikbud No. 21 tahun 2016 tentang Standar Isi Pendidikan Dasar Dan Menengah. Indonesia, 2016.

[2] Kemendikbud, Permendikbud No. 4 tahun 2018 tentang Penilaian Hasil Belajar oleh Satuan Pendidikan dan Penilaian Hasil Belajar. Indonesia, 2018.

[3] E. Mulyasa, "Kurikulum tingkat satuan pendidikan sebuah panduan praktis," Bandung PT Remaja Rosdakarya, 2007.

[4] BSNP, "Laporan Hasil Ujian Nasional Tahun Pelajaran 2015/2016," Tech. Rep. BSNP, 2016.

[5] BSNP, "Laporan Hasil Ujian Nasional Tahun Pelajaran 2016/2017." BSNP, 2017.

[6] BSNP, "Laporan Hasil Ujian Nasional Tahun Pelajaran 2017/2018," Tech. Rep. BSNP, 2018.

[7] V. L. Kelly, O. I. Oloyede, and E. Mkhumane, "An Investigation Into Misconceptions Held by Secondary School Chemistry Student."

[8] B. A. Sesen and L. Tarhan, "Promoting active learning in high school chemistry: Learning achievement and attitude," Procedia-Social Behav. Sci., vol. 2, no. 2, pp. 2625-2630, 2010.

[9] K. Sheppard, "High school students' understanding of titrations and related acid-base phenomena," Chem. Educ. Res. Pract., vol. 7, no. 1, pp. 32-45, 2006.

[10] A. Ö. I. ERDEM \.IR, Ö. GEBAN, and E. UZUNT\.IRYAK\.I, "Freshman students misconceptions in chemical equilibrium," Hacettepe Üniversitesi E^u\{g\}\}itim Fakültesi Derg., vol. 18, no. 18, 2000.

[11] A. Bernal-Ballen and Y. Ladino-Ospina, "Assessment: A Suggested Strategy for Learning Chemical Equilibrium," Educ. Sci., vol. 9, no. 3, p. $174,2019$.

[12] E. M. Omwirhiren and A. O. Ubanwa, "An Analysis of Misconceptions In Organic Chemistry among Selected Senior Secondary School Students in Zaria Local Government Area of Kaduna State, Nigeria," Int. J. Educ. Res., vol. 4, no. 7, pp. 247-266, 2016.

[13] F. A. Adesoji and A. G. Babatunde, "Investigating gender difficulties and misconceptions in inorganic chemistry at the senior secondary level," Int. J. African African-American Stud., vol. 7, no. 1, 2009.

[14] B. Yonata, W. Wasis, R. Sulaiman, E. Sudibyo, and M. S. Prastiwi, "PROFILE OF THE ACADEMIC COMPETENCY OF CHEMISTRY EDUCATION STUDENTS," in International Conference on Science and Technology (ICST 2018), 2018. 